\title{
A STUDY ON ARCHITECTURAL STYLE, STRUCTURE AND GEOMETRY IN THE OLD JEWISH QUARTER BUILDING STOCK OF BUDAPEST
}

\author{
ブダペスト、旧ユダヤ人居住地区における建物ストックの様式・構造・形態に関する研究 \\ Viktória SUGÁR ${ }^{* 1}$, Attila TALAMON ${ }^{* 2}$, András HORKAI*3, \\ Yuta NAGAI*4 and Michihiro KITA*5 \\ シュガー ヴィクトリア，タラモン アティラ，ホルカイアンドラーシュ，永井裕太，木多道宏
}

\begin{abstract}
The old Jewish Quarter of Budapest is a significant historical part of the Hungarian capital city, containing characteristic multi-story apartment houses with courtyard. Today, the unique values of the area are endangered. Demolitions destroy the buildings which are already in a run-down state.

Current paper is a first step of a complex research on the required rehabilitation. The Authors are analysing the architectural properties to find the historical characteristics.

As a result, clarification in the terminology of the architectural styles around the 19th-20th century was created, the typology of layout, the building materials, as well as their connection is analysed.
\end{abstract}

Keywords: Building Stock Analysis, Historical Apartment Houses, Building Typology, Building Rehabilitation 建物ストック分析，歴史的集合住宅，建物類型，建物修復

\section{Introduction}

The aim of this paper is to discuss the architectural heritage and its protection in case of Budapest residential building stock. Currently, the major part of downtown buildings in Pest area is in a poor condition, resulted by the lack of maintenance. Their physical characteristics are often not enough for today's health, economic or ecological requirements. Also, these buildings are densely inhabited, and extensive heating is used by the residents to against the cold weather.

The surveyed area of Budapest is referred as the "Old Jewish Quarter". Since the beginning of its development, the Quarter has been holding characteristic historical values, such as ornamented buildings and memories of Jewish culture. There are some protected monumental buildings in the area, but most of the stock is not sheltered from demolitions by law. Such unprotected buildings are often destroyed to be rebuilt as modern apartment houses or commercial buildings by real estate developments or modified to the point of losing their original values. Majority of the remaining unprotected buildings are in bad condition, so it is necessary to find solutions to cope with maintaining the unique architectural values of the area and improving energy efficiency for upgrading residential conditions.

This paper, as a first step of the survey, aims to identify the architectural values and characteristics of the Jewish Quarter building stock, based on not only architectural style, but also geometry, material and function. The geometry, material and also function are closely linked to the buildings' energy efficiency, thus the created typologies can be used for large-scale energetic calculations in the future.

\footnotetext{
*1 Assist. Lect., Ybl Miklós Faculty of Architecture, Szent István University, M.Arch.

*2 Assist. Prof., Ybl Miklós Faculty of Architecture, Szent István University, Ph.D.

* 3 Ph.D. Candidate, Ybl Miklós Faculty of Architecture, Szent István University, M.Arch.

*4 AZUSA SEKKEI Co., Ltd.

*5 Prof., Division of Global Architecture, Graduate School of Engineering, Osaka University, Dr.Eng.
}

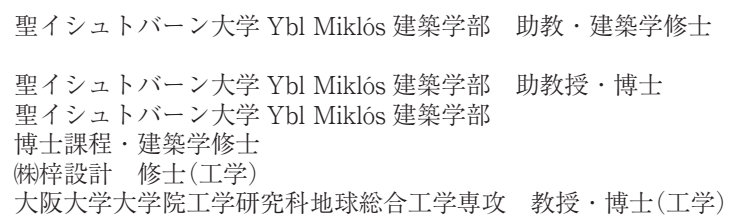




\section{Outline of the surveyed area}

Budapest is Hungary's capital and largest city. The area is situated in the statistical boundaries of Budapest $7^{\text {th }}$ District, bordered by Király Street, Erzsébet Boulevard, Rákóczi Street and Károly Boulevard, which runs parallel to the past medieval city walls (Fig.1,2). It contains the so-called Old Jewish Quarter of Pest.

This part of the downtown area, named Belső-Erzsébetváros (Inner-Elizabethtown), was an agricultural area until the 17th century. Today, 473 buildings are situated on $0,6 \mathrm{~km}^{2}$. The oldest building was built in 1811, the newest in 2016 .

Compared to its size, the population is high, its density is 25.899 person/ $\mathrm{km}^{2}$ 1) making it the most densely populated district of Budapest. Its evolution began spontaneously in the $18^{\text {th }}$ century, as the population of Pest started to outgrow the medieval city walls (Fig.1,2). As until the Patent of Toleration in 1782-1783, Jews were prohibited to enter the walled Pest, they first settled here, outside the city wall to $\operatorname{trade}^{2}$. The peak of the construction activities was between 1885 and 1915 . The characteristic building type of the time was the multi-story apartment house with courtyard, containing various flats, built for rent (Fig.3).

In the 1930's, the project of Madách Sugárút (Madách Avenue) had been the most grandiose intervention by demolishing the existing structures. A complex of 18 interlocking buildings were built with a great gate motif (called Madách houses) to open the densely built in inner parts. The plan, however, halted here due to the Second World War, and only the beginning of the Avenue was built (Fig.2,4).

The darkest period of the area was undoubtedly the time of the Holocaust. The Jewish Quarter became ghetto during the Second World War2). During the post-war renovations, some buildings damaged by bombings were demolished. Restricted number of new constructions were carried out in the following years due to the financial and post-war crisis.

At the beginning of the 1980 s, the renovation of historical districts begun here, first in the capital city. In 1988 , however the program was halted after renewal of three blocks because of financial reasons.

In the last two decades, Madách Avenue, currently called Madách Promenade, continued as an intervention in the original fabric with contemporary style buildings (Fig.2).

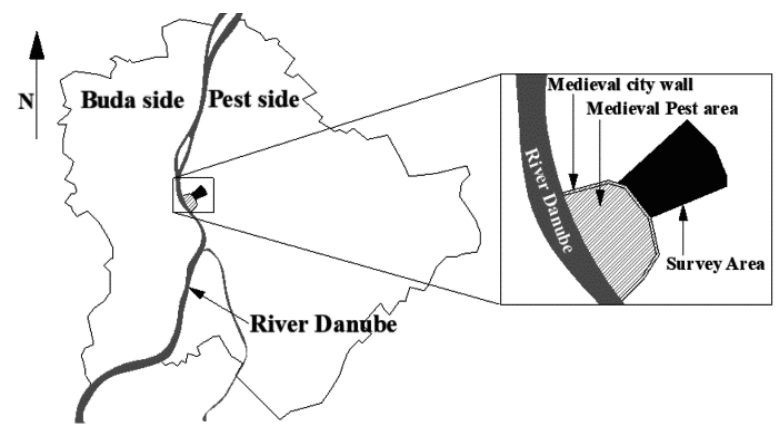

Fig.1 Situation of the Surveyed Area in Budapest
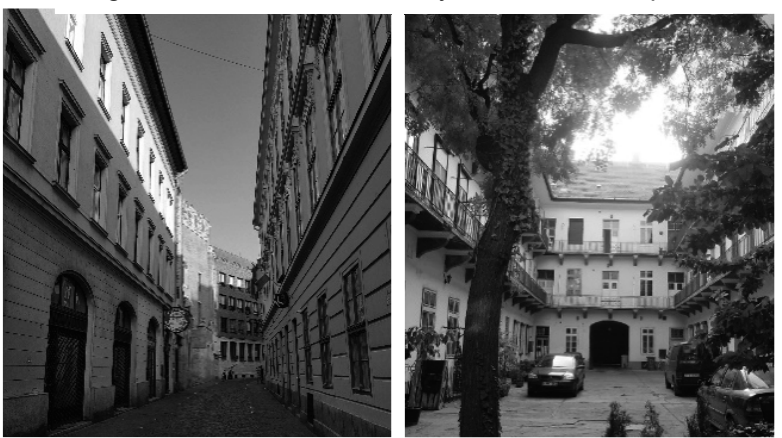

Fig.3 Photo of a Street (right) and Courtyard (left) of the Area Showing the Narrow Streets, and Dense Urban Fabric

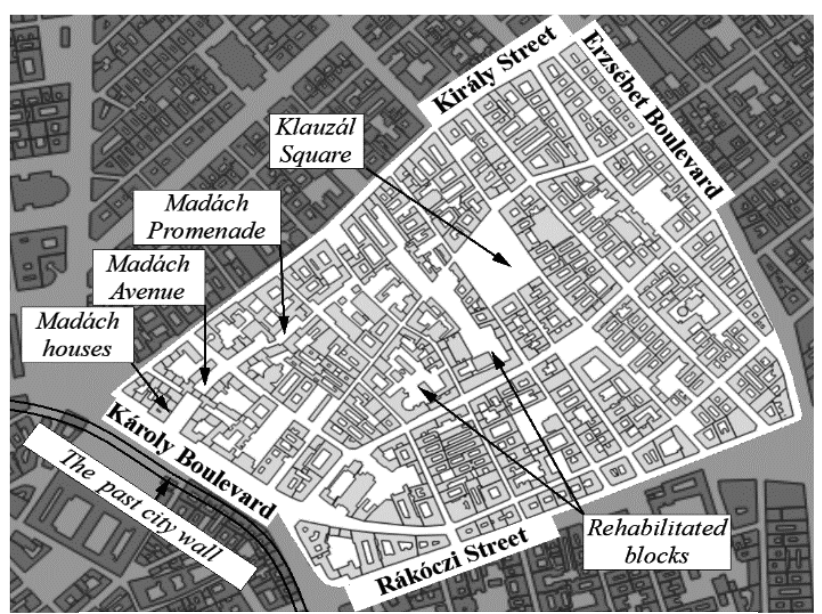

Fig.2 Map of Surveyed Area

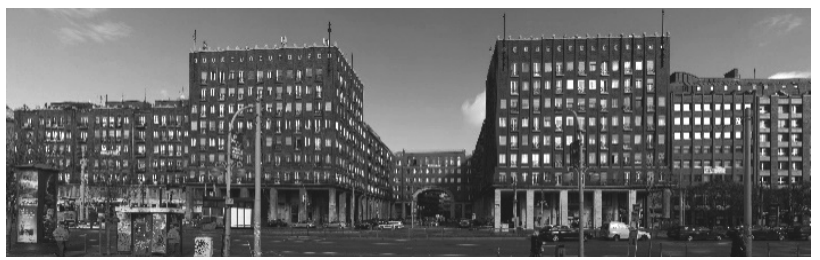

Fig.4 Madách houses brought a change of scale to the area.

The gate motif is in the middle of the picture (Photos are courtesy

of Rudolf Klein)

\section{Previous studies}

There have been several studies regarding the inner districts of Budapest focusing on historical and architectural questions. Specializing in the Old Jewish Quarter of Pest, Anna Perczel's outstanding research work ${ }^{2)}$ focuses on the unique, Jewish related buildings of the area, and was one of the first architectural books to draw attention to the endangered buildings of the area. Béla Nagy's survey for preparing the regulation plan on the area contains investigation of the building stock ${ }^{3)}$.

Not closely related to architecture, however an important study of Strbik et al.4) examines the history of the Jewish Quarters, describing important events, and the Jewish lifestyle, assisting the understanding of Jewish influence on the architecture of the area. 
Concerning architectural styles of the surveyed time range, the books of Sisa ${ }^{5)}$ 6), Ritoók ${ }^{7)}$ 8) Rados $^{9)}$ and Kalmár ${ }^{10)}$ should be mentioned. Also, Pattantyú ${ }^{11)}$ surveys extensively the building structures and materials used during in the characteristic residential houses of Pest. Edvi's book also offers information about the mandatory building structures and materials of the 19th century ${ }^{12}$. In his collective study, Déry summarizes the construction data of the buildings in the district ${ }^{13)}$.

Rudolf Klein, in his book introduced a matrix typology of synagogues, containing the Jewish Quarter examples ${ }^{14)}$. Nagai et al. revealed the process of transformation in urban fabric by analysing the memories of Jewish community15).

Based on the previous studies, it can be concluded, that several investigations have been created on the Old Jewish Quarter, however the typology and possibility of renovation of the full existing building stock has not yet been examined. About the past rehabilitation attempts, information can be found in the Authors' previous paper ${ }^{* 11}$.

\section{Framework and methodology}

\section{1. Framework of Study}

The study is built on three major steps as follows. This paper addresses the issues of Step 1.

(1) Step 1.: Categorization of 3 factors of all buildings: architectural style, enveloping structure (structural-material data) and geometry parameters, followed by the identification of relationships among the 3 factors. Architectural style is a simple representation of historical value, while the enveloping structure, its material, and geometry of a building are input data to evaluate energy parameters, and thus investigated to create typologies used in Step 2 calculations. If such relationships are defined, methodology of energy improvement with protecting the style will be achieved.

(2) Step 2.: Estimation of energy demand. Based on the European Union prescriptions, the Hungarian building energy calculation system contains the aspects such as characteristics of enveloping structures, geometry and engineering systems, which should all comply to the required low energy values. The aspects are built on each other, ensuring that the building in question, as a complex system reaches the desired low energy demand and utilization values ${ }^{16)}{ }^{17)}$. The typologies and results of Step 1 are used to simplify the large scale energetic calculations of Step 2. In this step, the energy demand is calculated to find characteristics and connections between the typologies, and to provide the information for simulations of Step 3.

(3) Step 3.: Simulations and discussion of improvement. Methodology of building improvement, which cope with maintaining values of architectural style and upgrading energy efficiency are discussed. Not only individual building, but also urban scale such as block, and district are assessed.

\section{2. Methodology of Current Paper (Step 1)}

\section{(1) Survey of building stock}

Information of each building, such as year of construction, history of modification, geometry, drawings, structure, and material, were investigated based on data of national archives, and historical books (Table 1). Data of around 80\% of buildings is incomplete in archives, or not mentioned in historical book, in consequence, interview, physical measurement, and photo documentation were utilized to complete the data of such buildings.

(2) Typology of Buildings

A survey on Architectural Styles was carried out based on literature source ${ }^{5-11}$ combined with data of Jewish Quarter to define the unique characteristics of style in the survey area. The layout (footprint) of each building was assessed and sorted into groups based on its main form, to define a typology. Structural-material typology was created based on characteristic utilized structures of each year. Using the typology, "packages" which summarized data of all enveloping structures were added to each building for Step 2. energetic calculations.

(3) Analysis of data

To clarify the special characteristics of Jewish Quarter, the above architectural style data was compared to previous studies. The distribution of styles in the survey area was also investigated. The relationship among architectural style, geometry, and package were assessed.

Table1 Type, source and period of investigation of data in Current Paper

\begin{tabular}{|c|c|c|}
\hline Data type & Source & Period of investigation \\
\hline Year of construction & Budapest City Archives, historical books²,13) & \multirow{2}{*}{ 2009-2015 } \\
\hline History of modification & Budapest City Archives, historical books ${ }^{2,4,13)}$, interview to owner/residents & \\
\hline Geometry (size of footprint, height, courtyard) & Budapest City Archives, satellite images ${ }^{18)}$, physical measurement $\left.{ }^{*}\right)$ & \multirow{2}{*}{ 2016-2017 } \\
\hline Drawings (plan, section, elevation) & Budapest City Archives, historical books²), photo documentation*) (façade) & \\
\hline Structure and material & Budapest City Archives, historical books ${ }^{11,12)}$, photo documentation, observation ${ }^{*}$ & 2017 \\
\hline
\end{tabular}




\section{Survey findings}

\section{1. Construction time range}

The number of constructions of the area was not constant during the surveyed period (between 1811 and 2016). Fig.5 shows the number of buildings constructed in each year for the current stock of building. The peak of the construction activities of the area was between 1885 and 1915 (A on Fig.5). The figure also shows clearly the periods of less construction, for example during the First World War (B) and during the financial crisis after Second World War (D) following them can be observed in the low number of new buildings. The peak around 1940 (C) shows the construction of Madách-houses, when significant part of the old fabric was replaced.

\section{2. Utilization of the stock - proportion of functions}

The predominant main function of the buildings is residential (81\%), the second is office (6\%) (Fig.6). Nearly all the buildings have at least one secondary function beside the main function, which is positioned on the ground floor or basement, on the street facade.

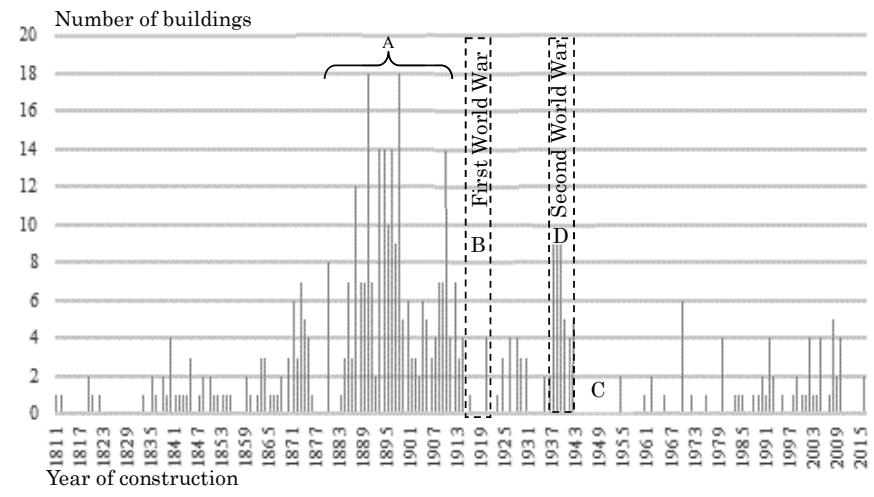

Fig.5 Number of Buildings by their Year of Construction (on Current Stock of Building)

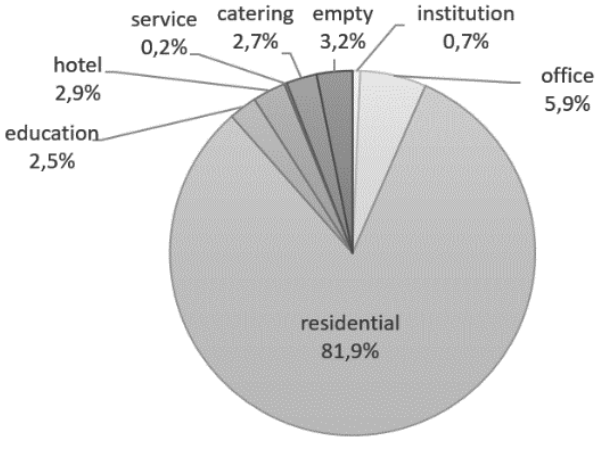

Fig.6 Ratio of Functions

\section{3. Geometry}

By investigating the footprint of each building and its position on the plot, six different types can be identified (Ideal shapes are shown on Fig.7.A; 1st row, examples in 2nd row): S-type is a Strip shaped form, L-type is L shaped layout, U-type is U shaped, two which two subgroups were added: in case of $\mathrm{U} 1$ type the bottom of the " $\mathrm{U}$ " is parallel to the street. In case of U2, the branch is parallel to the street. Ftype is Frame shaped, B-type is Block shaped, E-type marks the Empty plots. Combinations of the clear types can be found, although in small numbers, as shown on the bottom row of Fig.7.B.

$96 \%$ of the building stock can be sorted in the groups. The shapes created by multiplying or combining the types makes up $3 \%$ of the total quantity. It can be concluded, that the most characteristic type of layout is Frame type (F, 40\%). U type is second with $25 \%$ of ratio. U1 subtype and U2 subtype are in 2/3-1/3 proportion in U type. Examples for layouts of the most common styles are shown on Fig.7.C1, C2.

\section{A}

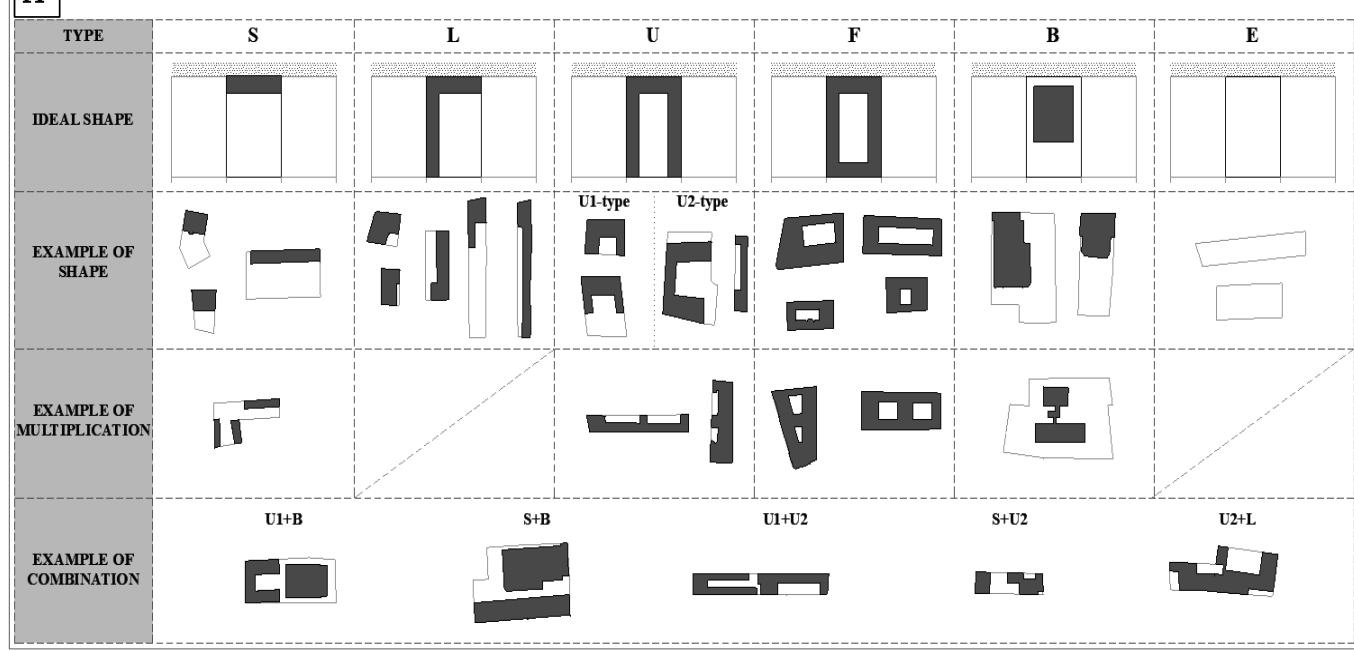

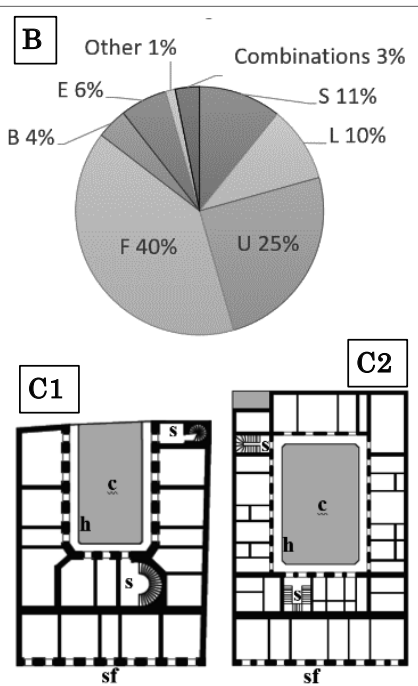

Fig.7 A: The Layout Typology of the Building Stock; B: The Distribution of Layout types; C: Example Layout of the Most Common U (C.1) and $\mathrm{F}(\mathrm{C} .2)$ Types (c=courtyard, h=hanging corridor, $\mathrm{s}=$ staircase, $\mathrm{sf}=$ street front facade) 


\section{4. Architectural styles}

There are 6 important previous studies, which identify the architectural styles ${ }^{6-11)}$. Most of them discuss limited period or functions in detail ${ }^{7,8,10,11)}$, while $\mathrm{Sisa}^{6)}$ and $\mathrm{Rados}^{9}$ analysed architecture in longer period, with more general information.

In this study the categories, characteristics and terminology of architectural style are identified referencing to three detailed studies ${ }^{7,8,11)}$, while time periods are surveyed on the long period studies 6 ,9).

In Table 2, characteristics mentioned in the three studies are assembled, to create categories for this study as follows: Neo-Classicism and Romanticism are in their commonly used meaning of the three studies. To clarify the meaning of the otherwise used Historicism, the Authors decided to narrow down the term only to describe the simpler geometry buildings using decorations of Renaissance-Baroque elements. Only Freestyle ${ }^{* 2}$ is new terminology, which was adapted to describe the buildings not clearly belonging to one style but mixing the decorative elements of Secession, Art Deco, Renaissance and Baroque architecture as well. These characteristics are in corresponding to the mostly similar meaning of subtypes 'Late-eclecticism' and Style-mixing historicism' mentioned in previous studies ${ }^{6,9}$.

In case the not, or little decorated, simple facades, flat roofs and more evolved layout (using closed staircases and corridors instead of hanging corridors) the Authors use the term Premodernism. Modernism, Socialist Modernism are used as their common definition of literature sources.

Table2 Style Characteristics and Drawings of Example Buildings

\begin{tabular}{|c|c|c|c|}
\hline 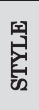 & CHARACTERISTICS IDENTIFIED IN THIS STUDY & 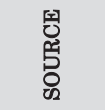 & $\begin{array}{l}\text { EXAMPLE STREET FRONT FAÇADE AND FIRST } \\
\text { FLOOR PLAN }\end{array}$ \\
\hline 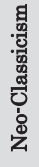 & $\begin{array}{l}\text { Clear, calm design, the elementary geometric bodies, aim for balance and symmetry. Style and } \\
\text { structure are closely connected. Ornaments follow structure. Using Greek-Roman classic order of } \\
\text { ornaments. The façade ornaments contain stone ledges dividing the stories as well as a crowning } \\
\text { the façade on the top. Their function other than decoration is to protect the façade from rainfall. } \\
\text { Building wings are designed around a courtyard with hanging corridors. }\end{array}$ & 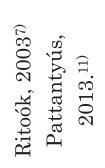 & 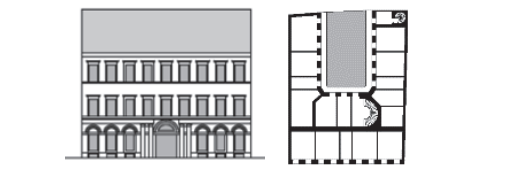 \\
\hline 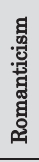 & $\begin{array}{l}\text { Differs from Classicism mainly in the theme of decoration. Uses Romanesque, Gothic, } \\
\text { Byzantine, or Oriental style decoration elements. } \\
\text { The openings are often semi-circular and Islamic hoof-shaped. }\end{array}$ & 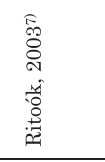 & 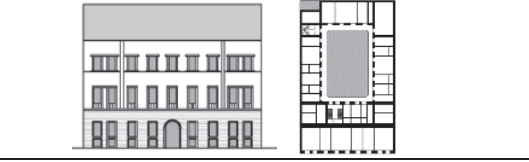 \\
\hline 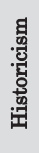 & $\begin{array}{l}\text { The approach towards the connection of style and structure: the structure and materials behind } \\
\text { the style elements and decoration were now fully separated from each other. The style can be } \\
\text { added at one's choice, as a changeable robe. In case of residential buildings, the Baroque and } \\
\text { Renaissance style elements as decoration were preferred. }\end{array}$ & 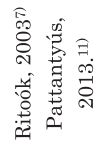 & 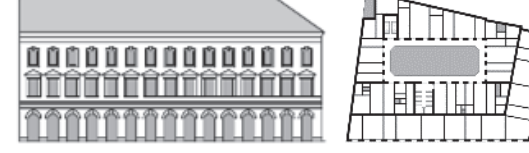 \\
\hline 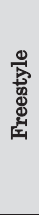 & $\begin{array}{l}\text { Layout and forming-wise even the apartment buildings still designed around a courtyard, using } \\
\text { hanging corridors. The heights became larger. The façade became more dynamic, the ordinary } \\
\text { flat geometry changed to swirling surface. The buildings were designed for lending resulting } \\
\text { several unhealthy, small apartments. The style elements mixed together are from various } \\
\text { sources: Secession and Art Deco elements can be spotted next to Renaissance-Baroque } \\
\text { decoration. }\end{array}$ & 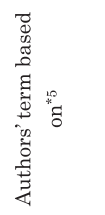 & 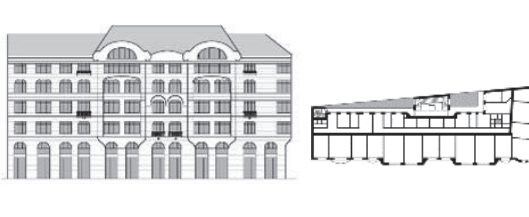 \\
\hline 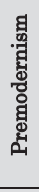 & $\begin{array}{l}\text { Simple geometry, less or no classic decoration on the façade, in most cases flat roof. The layout } \\
\text { of the apartment houses is mostly without a hanging corridor, the staircases were now closed } \\
\text { the flats were opened from the staircases and corridors. }\end{array}$ & 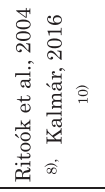 & 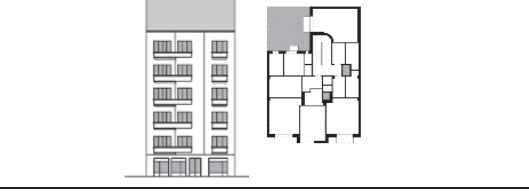 \\
\hline 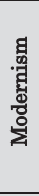 & $\begin{array}{l}\text { The facades are simple, plastered or stone paved, the windows unframed. Large glass surfaces } \\
\text { for lighting. } \\
\text { New, more liberal design methodology for layout. } \\
\text { The service rooms were often in the basement or on the flat roof. } \\
\text { Thinner structures of reinforced concrete or steel frames with modern fenestration raising new } \\
\text { building physics problems. }\end{array}$ & 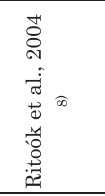 & 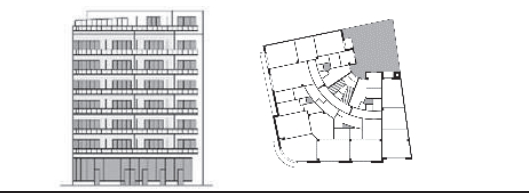 \\
\hline 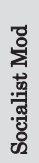 & $\begin{array}{l}\text { Prefabricated building structure, concrete frames with middle-size block and later full story- } \\
\text { high concrete sandwich panels. } \\
\text { The building design is not considering their surroundings, placed in an original fabric as } \\
\text { inclusions. }\end{array}$ & 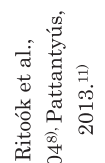 & 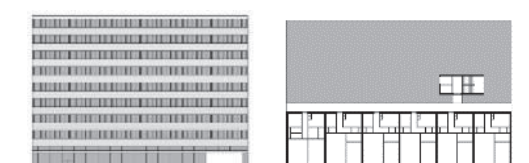 \\
\hline 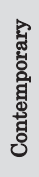 & $\begin{array}{l}\text { No exact characteristics to describe the contemporary multi-story apartment buildings yet. } \\
\text { Modernist and Post-Modernist elements can be spotted, as well as references to the historical } \\
\text { styles or High-tech elements. } \\
\text { The layouts are varied, the staircase-based, the closed corridor system, also, the hanging } \\
\text { corridor type design can be found. }\end{array}$ & 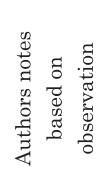 & 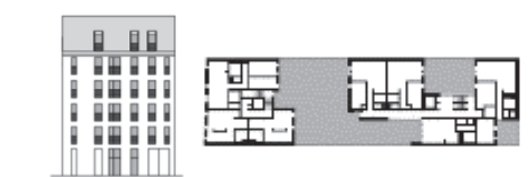 \\
\hline
\end{tabular}


Categorization of Table 2 is adopted to all buildings in the area. Result is shown in Fig.8: significant ratio of the buildings belongs to Historicism (39\%) and Freestyle (22\%). The Romanticism (2\%) Modernism (1\%) are the least significant styles.

Time range of the styles in the Jewish Quarter is shown in Fig.9, compared with the previous long period studies. The time range was defined specified to the Jewish Quarter, by observing the construction period of the all the buildings of each style.

It can be concluded, that there are differences between the periods of literature sources and the Jewish Quarter timeline: Neo-Classicism lasts longer, and all the other styles averagely began later and finished later than in literature sources. In case of Premodernism, however, the period fits the literature ${ }^{10)}$ which can be justified by the following: The Premodern style buildings of the area were mainly built by using district and city level, centralized master plans and prescriptions. The older styles are, however showing the more conservative taste of the individual investors.

For the distribution of the different styles in the surveyed area, it can be concluded, that the oldest part is Király Street, which is the north-western boundary of the area (Fig.2). The buildings first appeared alongside the major streets running south-west to north-east.

The oldest part of the current building stock (Neo-Classicism) thus can be found near Király Street. The Romanticist buildings are also near the older part. Historicism can be found spread on the area, but densifying on the north-eastern boundary, which is the Erzsébet Boulevard (Fig.2). Freestyle, Modernist and Socialist Modern style buildings can be found scattered. Premodern buildings are more densely built on the south-western corner (Madách houses), while Contemporary buildings are also scattered, densifying around the presently continued Madách Promenade and the rehabilitated blocks (Fig.2.).

As conclusion, the oldest and the newest buildings can be found in the same area (near Király street), showing, that most of the demolitions are rebuilding was suffered by the oldest and historically most significant part during the surveyed period.

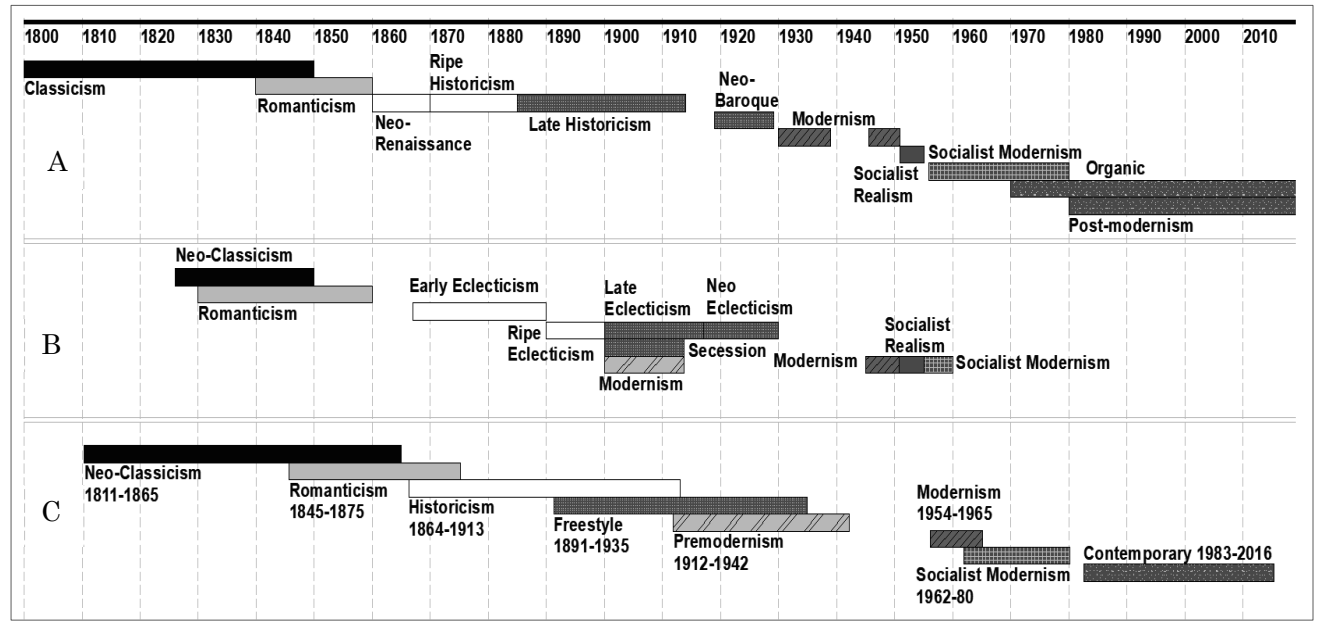

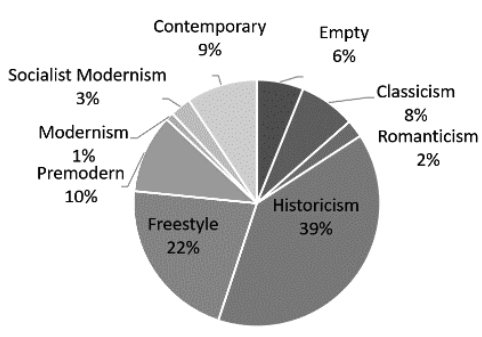

Fig.9 The Ratio of Architectural Styles

Fig.8 The Time Periods of the Styles: A. Sisa ${ }^{6}$, B. Rados ${ }^{9}$, C. Jewish Quarter

\section{5. Packages of Structure and Material}

Structure and material of buildings have been regulated strictly according to element, such as external wall, closing slab, cellar slab, fenestration, and so on, since the beginning of $19^{\text {th }}$ century. The present, good structural state and quality of the stock built in $19^{\text {th }}$ century is a result of this strict observance ${ }^{*}$ ) (although the primary structures as walls and slabs are in a good state, the secondary structures, for example fenestration and ornaments are in a run-down state).

Table3 Packages, Their Time Period and the Contained Building Elements

\begin{tabular}{|c|c|c|c|c|}
\hline \multirow{2}{*}{ Package } & \multicolumn{4}{|c|}{ Building Element } \\
\hline & External wall & Closing slab & Cellar slab & Windows \\
\hline Package 1 (1800-1840) & \multirow{3}{*}{ Brick-stone } & Covered beam & \multirow{3}{*}{ Vault } & \multirow{2}{*}{ Plank-type } \\
\hline Package 2 (1841-1850) & & \multirow{3}{*}{ Full timber $\left.{ }^{*} 5\right)$} & & \\
\hline Package 3 (1851-1860) & & & & \multirow{4}{*}{ Box-type } \\
\hline Package 4 (1861-1892) & \multirow{3}{*}{ Brick } & & Prussian vault ${ }^{*}$ ) & \\
\hline Package 5 (1893-1918) & & \multirow{3}{*}{ Reinforced concrete } & & \\
\hline Package 6 (1919-1930) & & & Steel with filling & \\
\hline Package 7 (1931-1954) & \multirow{2}{*}{$\begin{array}{l}\text { Hollow brick wall with } \\
\text { concrete frame }\end{array}$} & & $\begin{array}{l}\text { Reinforced concrete } \\
\text { with filling }\end{array}$ & \multirow{2}{*}{ Joint wing } \\
\hline Package 8 (1955-1980) & & $\begin{array}{l}\text { Advanced reinforced } \\
\text { concrete }\end{array}$ & $\begin{array}{l}\text { Advanced reinforced } \\
\text { concrete with filling }\end{array}$ & \\
\hline Package 9 (1981-) & $\begin{array}{l}\text { Reinforced concrete } \\
\text { with burnt clay }\end{array}$ & $\begin{array}{l}\text { Contemporary } \\
\text { reinforced concrete }\end{array}$ & $\begin{array}{c}\text { Contemporary } \\
\text { reinforced concrete } \\
\text { with filling }\end{array}$ & $\begin{array}{c}\text { Contemporary one-layer } \\
\text { PVC or wood }\end{array}$ \\
\hline
\end{tabular}

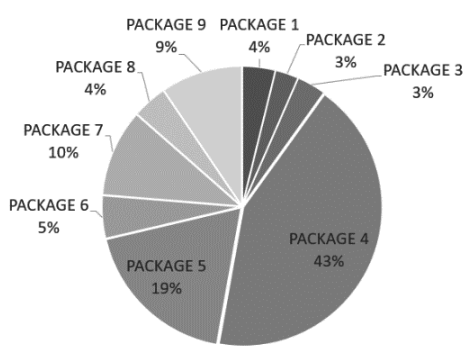

Fig.10 Distribution of Packages 
Information of these regulations are collected completely by Edvi ${ }^{12)}$ and Pattantyús ${ }^{11)}$. For example, external wall was usually created by brick-stone structure between 1800 to 1850 , and by brick structure between 1861 to 1930, due to the regulation and techniques of each period.

In Table 3, structure and material are specified according to the turning point of regulation and techniques in case of each building element. It is found that period is categorized into 9 groups based on combination of structure and material among the building elements. The category is named 'package', because assembled elements have a function, which envelope heated volume, for calculating energy demand of next step of this study. Categorization of package is adopted to all buildings in the area ${ }^{*}$ ). Consequently, the ratio of the packages is shown on Figure 10. The most significant is Package 4.

\section{6. Connection among Geometry, Packages, and Architectural Styles}

(1) Connection between style and geometry

Table 4. shows the correlation between the architectural style and layout form. The rows show the styles in approximately time order. The columns show the type of layout in order of complexity from simple to complex, from right to left. It can be concluded, that the most significant $\mathrm{F}$ and $\mathrm{U}$ types can be found in case of Historicism and Freestyle buildings. As an overall conclusion, as time goes, the F and U types are simplified to L and S types during the Premodernism and Social Modernism. The Contemporary style however use again various forms almost evenly.

(2) Connection between style and packages

Figure 11. shows the correlation between the architectural style and packages. The columns show the styles, while the different shades in rows show the packages. The most significant Package 4 can be found in case of Historicism with brick wall, full timber closing slab, Prussian vault cellar slab and box-type windows. The other most significant package 5 is in case of Freestyle, constructed by brick wall, reinforced concrete closing slab, steel with filling cellar slab, box-type window. Concrete frame is firstly adopted to Premodern buildings, where the simple forming was supported by the usage of frame structure. Contrary to Package 1-7, in case of Package 8 and 9 , less strict regulations and more possible building material for construction could be used. In case of these packages, a characteristic combination of elements was chosen to describe the period.

Table4 Correlation between Architectural Style and Geometry Elements

\begin{tabular}{|l|c|c|c|c|c|c|c|c|}
\hline Style/Type & B & S & L & U & F & COMB & E & Sum \\
\hline Empty & & & & & & & 29 & 29 \\
\hline Classicism & & & 3 & 18 & 14 & & & 35 \\
\hline Romanticism & & 1 & & 2 & 7 & & & 10 \\
\hline Historicism & 3 & 2 & 7 & 57 & 112 & 6 & & 187 \\
\hline Freestyle & 2 & 5 & 10 & 30 & 50 & 6 & & 103 \\
\hline Premodernism & 3 & 19 & 19 & 4 & 3 & & & 48 \\
\hline Modernism & 2 & 1 & 1 & 1 & & & & 5 \\
\hline Socialist Modern. & 2 & 10 & & 1 & & & & 13 \\
\hline Contemporary & 7 & 11 & 7 & 11 & 3 & 5 & & 44 \\
\hline Sum & 19 & 49 & 47 & 124 & 189 & 17 & 29 & 474 \\
\hline
\end{tabular}

[ratio of sub-total number] n: more than $50 \% \quad$ : more than $25 \%$

The numerical value in each column shows the number of the buildings

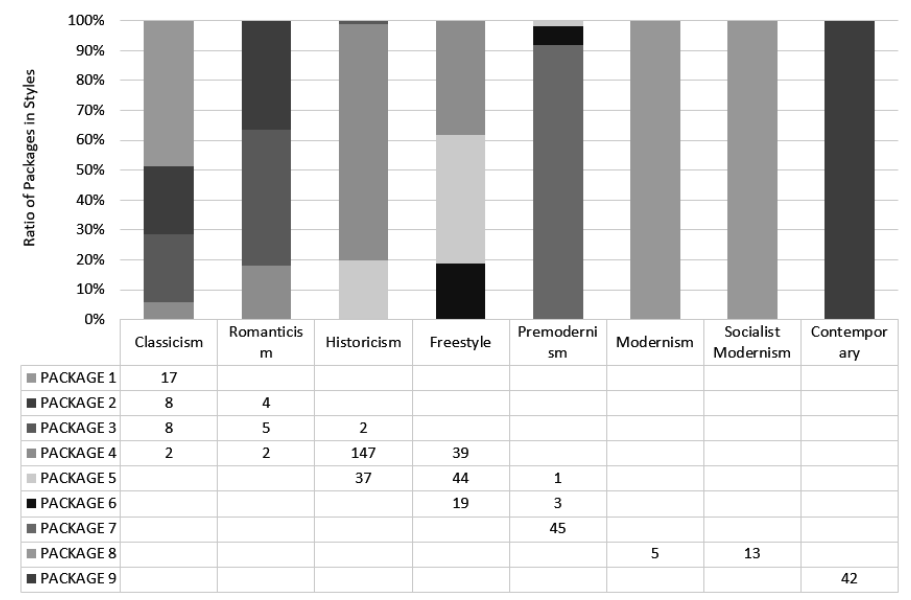

Fig.11 Correlation of Packages and Styles. The numerical value in each column shows the number of the buildings

\section{Conclusions}

In case of Jewish Quarter building stock, the rehabilitation is required to maintain the unique values. The complex rehabilitation should contain either heritage and energy efficiency measures. This paper, as a first step of a district scale rehabilitation survey introduces the architectural characteristics of the area. Surveys are based on geometry style, structure, material, and their correlation to each other.

A typology of geometry of the building stock was defined and its connection with architectural style was investigated. Present study introduces "S shape, L shape, U shape, Frame shape, and Block shape" types to describe the layout. The quantity of F (40\%) and the U (25\%) types are most significant of the area.

As a result of terminology survey, a modification of definition of architectural style for the area has been created. This study proposes, that in case of multi-apartment residential buildings of the turn of the $19^{\text {th }}$ and $20^{\text {th }}$ century, the name Historicism should be used only to describe buildings using mainly Renaissance-Baroque elements of decoration, and Freestyle to be used to describe the buildings containing mainly 
either Secession, Art Deco and other style elements, but not belong decisively in either group.

The survey of the connection between layout shapes and style shows that the most significant, and older styles, Historicism and Freestyle mostly designed as F or U shame layout. The newer styles use simpler geometry, mainly L or S shape.

For later energetic calculations, structural-material packages were created and assigned to time periods. It can be concluded, that the most characteristic package is package 4, containing brick wall, full timber closing slab, Prussian vault cellar slab and box-type windows. This package can be found mostly in case of Historicism buildings.

It is found, that the architectural style of a certain building has a close connection with its geometry and the above structural-material typology group. Architectural style thus was chosen for simple identification and classification of a certain building. This particular characteristic is convenient, because no complex information is required to determine the style. This simplicity is especially important, because one of the main aims of the study is, that the results should contribute as decision support system in future rehabilitation plans.

This paper examines the characteristics of the building stock. The energetic state, and the possibilities of district scale will be discussed in another study as next step.

\section{Reference}

1) Regional Statistical Yearbook of Hungary, Hungarian Central Statistical Office Budapest, p. 318., 2015

2) Perczel, A.: Védtelen Örökség - Unprotected Heritage, Lakóházak a Zsidó Negyedben- Residential Buildings in The Jewish Quarter; Budapest, Városháza, pp. 13-29., 2007

3) Nagy, B.: Budapest District 7 Inner-Elizabethtown Regulation Plan (Hun: Budapest VII. kerület Belső Erzsébetváros rehabilitációs szabályozási terve); Budapest, 2008

4) Strbik, A., Pusztai, V., Komoróczy, G. and Frojimovics, K.: Jewish Budapest (Monuments, Rites, History); Budapest, CEU Press, pp. 3-158., 1999

5) Sisa, J.: Hungarian Art in the 19th Century - Architecture and Applied Arts (Hun: A magyar múvészet a 19. században, Építészet és Iparmúvészet); Budapest, Müszaki Könyvkiadó, 2015

6) Sisa, J. and Wiebenson, D.: History of Architecture in Hungary (Hun: Magyarország építészetének története); Budapest, Vince Könyvkiadó. 1998.

7) Ritoók, P.: Hungarian Architecture 5. - Classicism, Historism (Hun:Magyar építészet 5. - Klasszicizmus, historizmus); Budapest, Kossuth kiadó, pp. 6-33., 96-109., 134-151., 2003

8) Ritoók, P., Fehérvári, Z., Hajdú, V. and Prakfalvi, E.: Hungarian Architecture 6. - From Secession to Present (Hun: Magyar építészet 6. - A szecessziótól napjainkig); Budapest, Kossuth Kiadó., pp. 6-37., 64-88. 2004

9) Rados, J.: Hungarian History of Architecture (Hun: Magyar építészettörténet); Budapest, Kossuth Kiadó., pp. 6-37., 64-88., 1961

10) Kalmár, M.: The History of Architecture 7. (Hun: Az építészet története 7.); Budapest, Terc Kiadó, 2016

11) Pattantyús, Á.: Building Rehabilitation - Reconstruction, Rebuilding and Strengthening of Load Bearing Structures (Hun: Épületrehabilitáció Tartószerkezetek helyreállítása, átépítése és megerôsítése); Budapest, TERC Kft., pp 13-17., 18-20., 20-25., 27-31., 31-36., 2013

12) Edvi, I. A.: Technical Guide of Budapest 1896 (Hun: Budapest múszaki útmutatója 1896); Budapest, Terc Kft., pp. 56-67., 2005

13) Déry, A.: Budapest Architectural Topography 3., Theresatown - Elizabethtown, 6th-7th District (Hun: Budapest építészeti topográfia 3. - TerézvárosErzsébetváros, VI-VII. kerület); Budapest, Terc Kiadó, 2006

14) Klein, R.: Zsinagógák Magyarországon 1782-1918 - Synagogues in Hungary; Budapest, Terc Kiadó, 2011

15) Nagai, Y., Yoshizaki, M., Miyahara, O., Kita, M. and Yoshioka, S.: Estimation of Relationships between the Memories of Urban Lives and Improvement of the Buildings - A study on Transformation of Shared Spatial System and Evolution of its Utilization in Jewish Quarter in Budapest Part 2, AIJ Kinki Chapter research meeting, Planning, Vol. 52, pp.45-48, 2012 (in Japanese)

永井裕太，吉崎 真人，宮原治，木多 道宏，吉岡聡司：都市居住の記憶と建物の増改築との関係についての考察 ブダペスト Jewish Quarter における街区内共 用空間系の変遷と活用状況の評価に関する研究 その 2, 日本建築学会近畿支部研究報告集, 計画系, 第 52 号, pp.45-48, 2012

16) Energy Performance of Buildings Directive European Union methodology https://ec.europa.eu/energy/en/topics/energy-efficiency/buildings (accessed 2018. 2. 15)

17) 7/2006. (V. 24.) Minister Without Portfolio Decree determining the energetic characteristics of buildings (Hun: 7/2006. (V. 24.) TNM rendelet: Az épületek energetikai jellemzóinek meghatározásáról), https://net.jogtar.hu/jogszabaly?docid=A0600007.TNM (accessed 2019. 1. 15)

18) Google maps web mapping service, www.google.com/maps (accessed 2018. 7. 10)

\section{Notes}

*1) About the uniqueness of the area and the previous rehabilitations and their results, as well as the monument protection of the buildings the following open source paper offers information: Viktória Sugár, Attila Talamon, András Horkai, Michihiro Kita: Assessment of Rehabilitation Possibilities in Case of Budapest Jewish Quarter Building Stock, In: World Academy of Science Engineering and Technology 11:(3) Pp. 373-379. (2017)

*2) The term Freestyle is chosen to describe the style mixing nature of the period. The origin of the term is: "Late-C19 style in which Classical, Domestic Revival, Gothic, Queen Anne, and vernacular themes, motifs, and elements were mingled promiscuously in eclectic compositions, sometimes with additional Elizabethan or Renaissance allusions added (...)". Source: encyclopedia.com.

*3) For example, after the buildings' load bearing structures were built, it was left in that state for 1 year, to confirm its quality ${ }^{12)}$.

*4) By using photo documentation of damaged structures of buildings in the area, the literature data were confirmed as the collected data. For example: in case the mortar fell from walls or there is damage in the slab, the structure is shown.

*5) Full timber closing slab became mandatory to use because of its better fire resistance than covered beam. The structure is composed fully of timbers connected to each other, with filling on top.

*6) Prussian vault is a characteristic slab structure of the $19^{\text {th }}$ century. It is constructed by steel beams and narrow brick vaults in between with filling. 


\section{和文要約}

1. はじめに

本研究は、ブダペストの主要部に位置する旧ユダヤ人地区（Old

Jewish Quarter）を対象に、建築遺産とその保護について考察する ことを目的とする。当地区は建物の維持管理が不十分なため老朽化 が著しく、寒冷な気候による健康上の問題も生じている。また、膨 大な暖房のコストにより、経済性や環境面でも問題がある。

当地区は市街地形成の当初から、美しい装飾のされた建物群とユ ダヤ文化の記憶といった歴史的価值を帯び続けてきた。保護建築に 指定された建物は幾つかあるが、大半は未指定であり、ディベロッ パーによるアパートや商業施設への建て替えや、原型の特徵が喪失 されるような改造が進んでいる。残された建物の多くは老朽してお り、これらの喪失を防ぐためには、建築固有の価值の維持と、居住 性能を向上させるエネルギー効率の改善を両立する方法論の開発が 必要である。本研究は、その第一段階として、旧ユダヤ人地区の建 築的特徴について、建築様式のみならず、エネルギー効率に影響す る形態や構造材料の面から明らかにすることを目的とする。

\section{2. 調查対象地区の概要}

旧ユダヤ人地区は、現在の第 7 区行政区域に位置する。元来は旧 市壁の外側に隣接する農地であったが、18 世紀になると市街化が始 まった。ユダヤ人は、1782-1783 年に許可が降りるまでは市壁の内 側に入ることが許されなかったため、当地区に居住し、交易を行っ たのである。1930 年代になるとマダーチ通りの建設が開始された。 これは既存の建物群を解体しながら、南から北へと街路を貫通させ る計画であった。最初に 18 棟もの建物からなるゲート状の建造 物・マダーチハウスが建設され、稠密な都市組織に街路を切り開く シンボルとなった。しかし、第二次世界大戦の混乱により、街路の 建設は中断されるところとなった。

当地区に最も暗い影を落としたのはホロコーストである。第二次 世界大戦中、当地区がユダヤ人ゲットー地区に指定された。戦後は 1980 年代初めに歴史的地区としての修復が開始されたが、1988 年 には財政難を理由に 3 街区の改造を終えたところで中断された。

第二次世界大戦で中断されていたマダーチ通りの建設は、名称を マダーチプロムナードと変えて再開され、この 20 年の間に路線上 の都市組織を除却しながら整備が進められてきた。その結果、その 沿道には現代的なスタイルの建物群が立ち並ぶこととなった。

3. 既往研究

Anna Perczelによる書籍「保護されない遺産」を初めとして、当 地区における建築の意匠的特徵やユダヤ人の生活文化の歴史をまと めた文献がある。しかし、本研究のようにエネルギー性能の改善可 能性の観点から意匠や材料・構造の実態を調査したものは無い。

\section{4. 本研究の骨格と方法論}

研究は 3 段階からなり、本論文は第 1 段階の成果を報告する。 - 第 1 段階（建築様式、構造 - 材料、形態の 3 指標類型と相互の関 係性の特定）：第 2 段階では構造・材料と形態を用いてエネルギー 需要を算定するため、3 指標の関係性を解明することで、建築様 式を維持しながらエネルギー効率を改善するための知見を得る。 - 第 2 段階（エネルギー需要の推定）: 第 1 段階で得た指標とその值 を用いることにより、全建物のエネルギー需要を算定し、第 3 段 階のためのデータを得る。
・第 3 段階（改善のシミュレーションと考察）：建築的価値の維持と エネルギー効率の向上を両立する建物改善手法について考察し、

建物単体レベルと街区・地区レベルの効果について検証する。

5. 調查結果

5.1. 建設時期

建物の建設件数は 1885 年から 1915 年がピークであったが、第一 次世界大戦と第二次世界大戦後の経済危機では建設数が低減した。 5.2. 建物用途

$81 \%$ の建物は住宅、6\%がオフィスである。ほとんどの建物は道 路沿いの 1 階か地階に別の用途を持っている。

5.3. 建物形態

建物の平面形と敷地における配置を検討したところ、S、L、U、 $\mathrm{F} 、 \mathrm{~B} 、 \mathrm{E}$ の 6 タイプとこれらの複合型に分類することができた。F タイプが $40 \%$ と最も多く、次いでUタイプが $25 \%$ 占めた。

5.4. 建築様式

3 つの既往研究を図式化し、建築様式の分類、特徵、用語を検討 した。ネオクラシシズムとロマンチシズムについては、既往研究に 共通する定義を採用した。ヒストリシズムは狭義の意味を独自に設 定し、ルネサンスとバロックの装飾を用いた単純な形態の建物に用 いることとした。セセッション、アールデコ、ルネサンス、バロッ クの要素で混成される様式は新たにフリースタイルと名付けた。

少ない装飾、シンプルなファサード、陸屋根、閉じた廊下のレイ アウトの特徴を併せ持つ様式をプレモダニズムと定義した。モダニ ズム、社会主義モダニズムは、既往研究の定義と同様とした。

全建物について様式を特定したところ、ヒストリシズムが $39 \%$ と 最も多く、次いでフリースタイルが $22 \%$ であった。

5.5. 建築外皮 (Package)

建物の構造材料は、19 世紀初めから外壁、スラブ、基礎スラブ、 空などの要素に応じて法律で厳格に規制されてきた。時代ごとの規 制内容を整理し、外壁・スラブ・基礎スラブ・空に対して義務付け られた構造材料の組み合わせを分類すると 9 パターンを得た。

5.6. 形態・建築外皮・建築様式の関係

建築様式と建物形態の関係を図式化したところ、クラシシズムか らヒストリシズム、フリースタイルにかけて、F 型と U 型などの高 密な形態が主流であるが、プレモダニズスから社会主義モダニズム にかけて単純な形態が採用されたことがわかった。

建築外皮との相関を検討したところ、最も事例数の多いパッケー ジ４は、煉瓦造の壁、木造スラブ、プロセインヴォールト基礎スラ ブ、箱型空で構成されたヒストリシズムとフリースタイルの建物に 見られ、次に多いパッケージ5 はフリースタイルの建物の過半を占 めることがわかった。

6. 結論

エネルギー需要の算定に有効な材料構造の類型方法を検討した結 果、建築外皮による類型が有効であることがわかった。これを全建 物に適用したところ、ヒストリシズムとフリースタイルの建物の大 半がパッケージ 4 と 5 で構成されており、プレモダニズムはパッケ ージ 7 であることが明らかとなった。今後は、パッケージの指標を 用いたエネルギー需要の算定を行い、各スタイルの特徴を継承する ための改善手法を検討する。

(2018 年 9 月 2 日原稿受理, 2019 年 4 月 17 日採用決定) 